\title{
Bibliometric study of tourism destination image in Science Direct
}

\section{Estudio bibliométrico sobre imagen de destinos turísticos en Science Direct}

\section{Ernesto Batista Sánchez ${ }^{1 *}$, Beatriz Serrano Leyva ${ }^{2}$ and Elizabeth del Carmen Pérez Ricardo ${ }^{3}$}

\footnotetext{
${ }^{1}$ M.Sc. Tourism Management, Kemmy Business School, University of Limerick, Limerick, Ireland

2 B.Sc. Tourism, Department of Tourism, University of Holguin, Holguin, Cuba

${ }^{3}$ B.Sc. Tourism Management, Department of Tourism, University of Holguin, Holguin, Cuba

* Corresponding author (E-mail corresponding author): ebatistasqyahoo.com
}

\begin{abstract}
Tourism destination image has been the centre of interest of several research last decades. This research aimed to develop a bibliometric analysis with retrospective-descriptive purposes on the academic international production available in Sciencedirect between 1997 and 2008. The scientific production was classified and analysed employing several bibliometric indicators, among which the following stand up: productivity by authors, chronological variations in the publications and research lines analysis. The analysis was developed using "TOURISM" AND "DESTINATION IMAGE" in the published articles. For the content analysis were employed the following software: Endnote X7, Bibexcel, Excel, Pajec and VOSviewer. The main results show the increase in the interest related to this construct, being Tourism Management the most productive journal. Furthermore, gaps were identified for forthcoming research related to big data analytics and its impact on the formation process of the tourism destination image.
\end{abstract}

Keywords: destination image, bibliometric analysis, tourism

\section{RESUMEN}

La imagen de destinos turísticos ha sido el objeto de estudio de numerosas investigaciones en las últimas décadas. La presente investigación tuvo como objetivo realizar un estudio bibliométrico con carácter retrospectivo descriptivo sobre la producción científica internacional de este constructo disponible en Sciencedirect entre 1997 y 2018. La producción científica fue clasificada y analizada a partir de diversos indicadores, entre los que se encuentran la productividad por autores, la variación cronológica de las publicaciones y el análisis de líneas de investigación. Se utilizaron las palabras claves "TOURISM"AND "DESTINATION IMAGE" en artículos originales publicados por revistas. Para el procesamiento y análisis de la información se utilizaron los softwares Endnote X7, Bibexcel, Excel, Pajek y VOSviewer. Los principales resultados muestran el crecimiento en el interés vinculado a esta temática, siendo Tourism Management la revista más productiva. Además, se identificaron brechas para futuras investigaciones destacándose el análisis de big data y su impacto en la formación de la imagen de destino.

Palabras clave: imagen de destino, análisis bibliométrico, turismo 


\section{INTRODUCTION}

Nowadays tourism sector faces several challenges linked to market positioning and differentiation from competence to satisfy an increasingly exigent demand. Within this context, tourism destination image management plays a key role to achieve success, determined into a great extent in how potential customers perceive the destination itself from the formation of the induced image.

Although this research topic has become more important in recent years, the interest of scholars about this construct started in the '60s of the 20th Century. First research to deal with this issue was Boulding (1956), who suggested that image could have a bigger impact on human behaviour rather than objective information about a perceived object or the environment. On the other hand, the application of the concept of image to places and research started in the '70s of the 20th Century from different disciplines (Gallarza, Saura, \& García, 2002). Precisely these types of research play a key role in tourism due to its impact on the marketing of tourism destinations.

Most of the research conducted on tourists perceptions focuses on the concept of destination image, which is defined as the perceptions of the destination attributes from individuals and its holistic impression... that consists of the functional characteristics related to the tangibles aspects and the psychological characteristics related to the intangible aspects (Echtner \& Ritchie, 1993).

From the previous statements can be concluded why tourism destination image became popular research topics in tourism since it has been demonstrated its influence in the choice, satisfaction and post purchasing behaviour (Ramseook-Munhurrun, Seebaluck, \& Naidoo, 2015). Even more, information and communication technologies have a great impact in the formation of TDI, since tourism web sites can proportionate virtual experience to tourism about a destination and influence the formation and positioning of the image (Doolin, Burgess, \& Cooper, 2002). Management of image and its perceptions are the core of tourism advertising in the media.

Therefore, the management of image from social media is essential for tourism managers. Even more, the comprehension of the antecedents of destination image among residents and tourists; and their behavioural intentions offers destination management organizations (DMO's) additional opportunities to improve their image (Stylidis, Shani, \& Belhassen, 2017). In this way, DMO's can develop strategies oriented to improve tourists perceptions (Sanz, 2008).

These reasons justified the need on analysing this research topic and the statements on literature, although the various contributions to the construct, it seems to be a generalized agreement on the interpretation of the destination image as a subjective and multidimensional construct (Tasci, Gartner, \& Cavusgil, 2007)

One of the tools that provide insights into the research is bibliometric, thus academic and scientific literature in several research areas have grown with an unprecedented dynamic. Furthermore, the development of academic online datasets has increased the opportunities for access to research at any time worldwide. Nowadays exist a growing need to evaluate the production and communication process of knowledge in educational sciences and the product of the scientific activity

Bibliometry can be defined as a technique of bibliological research that aims at, on one side, to study the size, growing and distribution of the bibliography in a specific field, and on the other side, study the social structure of the groups that produce it and employ it. Bibliometric scores provide quantitative and objective information about the results of the research process. They are employed to measure the quality of scientific papers -in example, productivity- or the impact of the papers -citation scores, trends analysis- (Dávila et al., 2009).

\section{METHODOLOGY}

This bibliometric study possesses a descriptive retrospective character being analysed original articles about tourism destination image in the period 1997-2018 published on peer-reviewed journals and hosted in Science Direct. The data for this analysis was obtained through the search of the next parameters: "Tourism" AND "destination image".

From each article where extracted Title, Full name of the authors, Year of publication and Journal Name. This information was processed using Endnote $\mathrm{X} 7$ software to correct duplicated outcomes and then Bibexcel (v2016- 
02-20) and Microsoft Excel for the analysis of production indicators, references actuality and statistical analysis of the data. In addition, the outcomes of Bibexcel allowed to analyse the collaboration indicators, generate the collaboration network map using Pajek software and the correspondence maps of the thematic descriptors using voSviewer 1.6.8.

\section{RESULTS AND DISCUSION}

\section{Productivity of articles (1997-2018)}

In the 1997-2018 period were published 987 original articles and research was divided in seven years period. The first period, 1997-2004 had the lowest productivity, with a total of only 64 papers. From 2004 there is evidence of an increase in the research, coinciding with the emergence of web 2.0 that brought higher importance to this area of study. From 2005-2011 a total of 197 articles where published, amount approximately three times bigger than the previous period. However, the higher productivity was developed between 2012-2018 with 726 papers, which evidence the increasing interest in this construct and its accelerated growing.

Figure 1. Published papers per year

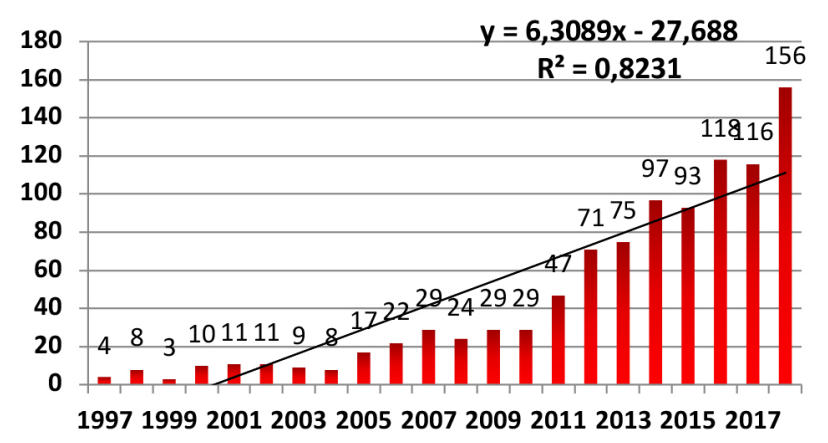

\section{Productivity per journals}

The academic journals where authors publish the most where Tourism Management with a total amount of 350 articles, representing a $35 \%$ of the total, followed by Annals of Tourism Research with 134 articles (14\%),
Journal of Destination Marketing \& Management with 125 (13\%), Tourism Management Perspectives with 73 articles (7\%) and the journal Procedia - Social and Behavioural Sciences with 61 articles, representing 6\% of the total. These journals concentrate the $75 \%$ of the total published articles. The other $25 \%$ is distributed as follows: 5 journals published 145 articles distributed in $46,35,33,16$ and 11 respectively; 2 journals only published 5 articles each; seven published three articles each, while 12 and 36 journals published 2 and 1 each respectively.

\section{Table 1: Articles in the main journals}

\begin{tabular}{|c|c|c|c|}
\hline Journal & $\#$ & $\%$ & Accum.(\%) \\
\hline Tourism Management & 350 & 35,46 & 35,46 \\
\hline $\begin{array}{l}\text { Annals of Tourism Research } \\
\text { Journal of Destination }\end{array}$ & 134 & 13,57 & 49,03 \\
\hline $\begin{array}{l}\text { Marketing \& Management } \\
\text { Tourism Management }\end{array}$ & 125 & 12,66 & 61,70 \\
\hline $\begin{array}{l}\text { Perspectives } \\
\text { Procedia - Social and }\end{array}$ & 73 & 7,39 & 69,09 \\
\hline Behavioral Sciences & 61 & 6,18 & 75,27 \\
\hline
\end{tabular}

\section{Actuality of the references}

The analysis of the bibliographic reference's actuality was developed using Price index that shows the rate of references with five or fewer years. From the 987 analysed articles, 580 belongs to the last five years, for a reference actuality of 0.59 , which is considered high in this type of research.

Furthermore, Price index was used to analyse the most productive journals, where Journal of Destination Marketing \& Management presents the higher score of 0.9 while Annals of Tourism Research presented the lowest score since from its 134 articles, only 39 belongs to the last five years period. 
Table 2: Price index of selected journals

\begin{tabular}{|l|c|c|c|}
\hline Journal & $\begin{array}{c}\text { Total of } \\
\text { articles }\end{array}$ & $\begin{array}{c}\mathbf{5} \mathbf{5} \\
\text { years }\end{array}$ & $\begin{array}{c}\text { Price } \\
\text { Index }\end{array}$ \\
\hline Tourism Management & 350 & 163 & 0.47 \\
\hline $\begin{array}{l}\text { Annals of Tourism Research } \\
\text { Journal of Destination }\end{array}$ & 134 & 39 & 0.29 \\
\hline Marketing \& Management & 125 & 112 & 0.90 \\
\hline $\begin{array}{l}\text { Tourism Management } \\
\text { Perspectives }\end{array}$ & 73 & 59 & 0.80 \\
\hline $\begin{array}{l}\text { Procedia - Social and } \\
\text { Behavioral Sciences }\end{array}$ & 61 & 46 & 0.75 \\
\hline
\end{tabular}

\section{Personal productivity}

The review showed a total of 501 authors in total. From then, the most prominent authors are presented in the following table. Among them, the most productive were Xian Li with 11 articles, Cris Ryan and Svetlana Stepchenkova with 9 articles each and Alastair M. Morrison, Bob McKercher and Steven Pike with 8 articles each.

\section{Table 3: Personal productivity}

\begin{tabular}{|l|c|}
\hline Authors & Number of published articles \\
\hline Xiang Li & 11 \\
\hline Chris Ryan & 9 \\
\hline Svetlana Stepchenkova & 9 \\
\hline Alastair M.Morrison & 8 \\
\hline Bob McKercher & 8 \\
\hline Steven Pike & 8 \\
\hline James F. Petrick & 7 \\
\hline Dimitrios Buhalis & 7 \\
\hline Seyhmus Baloglu & 7 \\
\hline Philip L.Pearce & 6 \\
\hline Hany Kim & 6 \\
\hline Brian Garrod & 6 \\
\hline
\end{tabular}

Relationship of the most productive authors and journals Most of the published articles by the most productive authors were in the main journals mentioned in Table $(X)$, and its distribution is presented in table 4. Among them are Xian Li and James F. Petrick who published all their articles in some of these journals.

From the 92 articles published by the most productive researchers, 74 published in the most productive journals, which represents $80 \%$ of the total. Among them are Tourism Management and Journal of Destination Management and Marketing with $69 \%$ and $14 \%$ respectively. On the other side, evidence shows that 51 of the 350 articles in Tourism Management where conducted by the most productive authors

Figure 2. Principal journals used by the productive authors

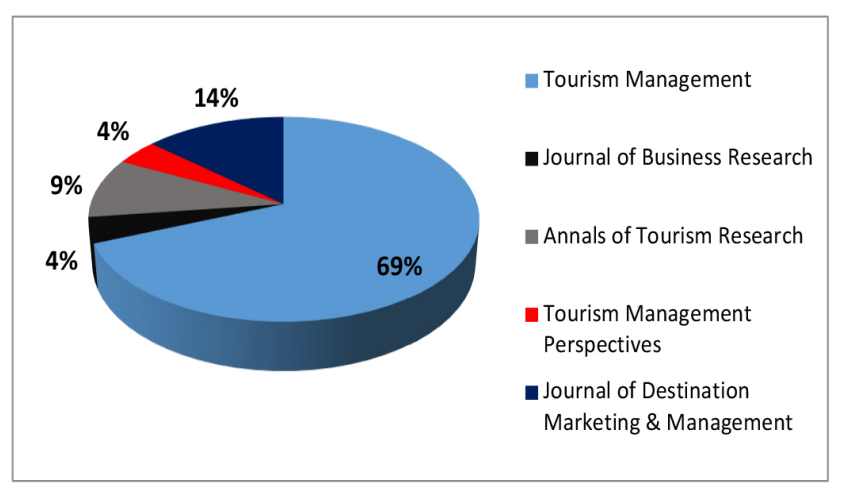

\section{Number of authors per article}

The maximum number of authors per article was seven (Table 5) and there is a predominant number of papers published by two or three authors, which represents $35.97 \%$ and $30.70 \%$ respectively.

\section{Table 5: Number of authors per article}

\begin{tabular}{|c|c|c|}
\hline Authors & Articles & \% \\
\hline 1 & 160 & 16,21 \\
\hline 2 & 355 & 35,97 \\
\hline 3 & 303 & 30,70 \\
\hline 4 & 125 & 12,66 \\
\hline 5 & 29 & 2,94 \\
\hline 6 & 13 & 1,32 \\
\hline 7 & 2 & 0,20 \\
\hline Total & $\mathbf{9 8 7}$ & $\mathbf{1 0 0 , 0 0}$ \\
\hline
\end{tabular}




\section{Social collaboration analysis}

Social collaboration analysis is described in the red nodes of figure 3. The total number of authors was 1053 and the average of authors per article was 1.06.

\section{Distribution of authors with productivity levels}

Table 6 presents the distribution according to the productivity level (small, medium and high). $38.1 \%$ of the authors are small level producers while $61.6 \%$ are medium-level producers. Only $0.19 \%$ (1 author) belongs to a high productivity level.

\section{Table 6: Productivity levels}

\begin{tabular}{|c|c|c|c|}
\hline \multirow{2}{*}{ Classification } & \multirow{2}{*}{ Articles } & \multicolumn{2}{|c|}{ Frequency } \\
\cline { 2 - 4 } & & $\mathbf{n}$ & $\mathbf{\%}$ \\
\hline High level & 10 o más & 1 & 0.19 \\
\hline Medium level & $2-9$ & 309 & 61.6 \\
\hline Small level & 1 & 191 & 38.1 \\
\hline Total & & 501 & 100 \\
\hline
\end{tabular}

\section{Principal research lines}

Figure 4 presents the relationship between the research nodes found in the 987 articles about tourism destination image between 1997 and 2018. The most frequent key words according to the map are destination image, tourism, social media and tourism marketing, among others.

Figure 4. Published papers per year

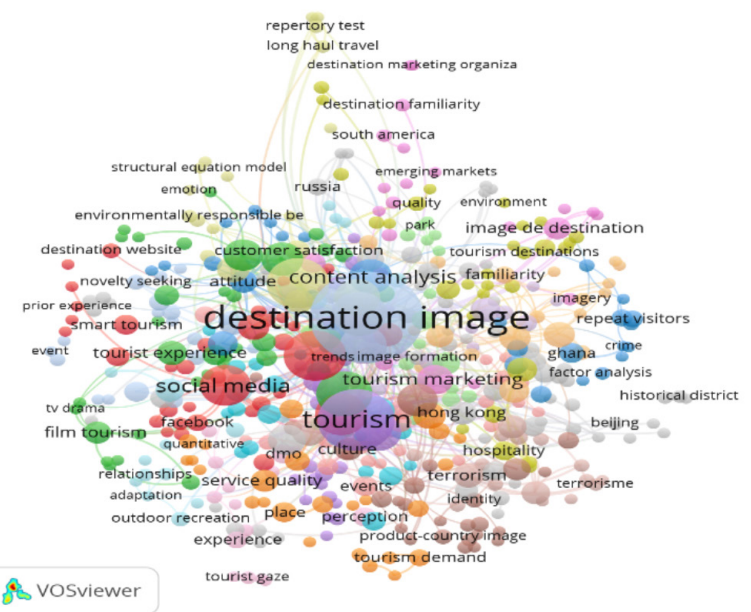

Table 4: Productivity levels

\begin{tabular}{|c|c|c|c|c|c|c|c|}
\hline Authors & $\begin{array}{l}\text { Total of } \\
\text { articles }\end{array}$ & $\begin{array}{c}\text { Tourism } \\
\text { Management }\end{array}$ & $\begin{array}{l}\text { Journal } \\
\text { of Business } \\
\text { Research }\end{array}$ & $\begin{array}{l}\text { Annals of } \\
\text { Tourism } \\
\text { Research }\end{array}$ & $\begin{array}{c}\text { Tourism } \\
\text { Management } \\
\text { Perspectives }\end{array}$ & $\begin{array}{l}\text { Journal of } \\
\text { Destination } \\
\text { Marketing \& } \\
\text { Management }\end{array}$ & $\begin{array}{l}\text { Other } \\
\text { journals }\end{array}$ \\
\hline Xiang Li & 11 & 7 & 2 & 2 & & & 0 \\
\hline Chris Ryan & 9 & 5 & & & 2 & & 2 \\
\hline Svetlana Stepchenkova & 9 & 5 & & & & 2 & 2 \\
\hline Alastair M.Morrison & 8 & 7 & & & & & 1 \\
\hline Bob McKercher & 8 & 4 & & 3 & & & 1 \\
\hline Steven Pike & 8 & 4 & & & 1 & 2 & 1 \\
\hline James F. Petrick & 7 & 5 & & 1 & & 1 & 0 \\
\hline Dimitrios Buhalis & 7 & 4 & & & & 2 & 1 \\
\hline Seyhmus Baloglu & 7 & 5 & & & & & 2 \\
\hline Philip L. Pearce & 6 & 2 & 1 & 1 & & & 2 \\
\hline Hany Kim & 6 & & & & & 3 & 3 \\
\hline Brian Garrod & 6 & 3 & & & & & 3 \\
\hline Total & 92 & 51 & 3 & 7 & 3 & 10 & 18 \\
\hline
\end{tabular}


Figure 3. Social collaboration

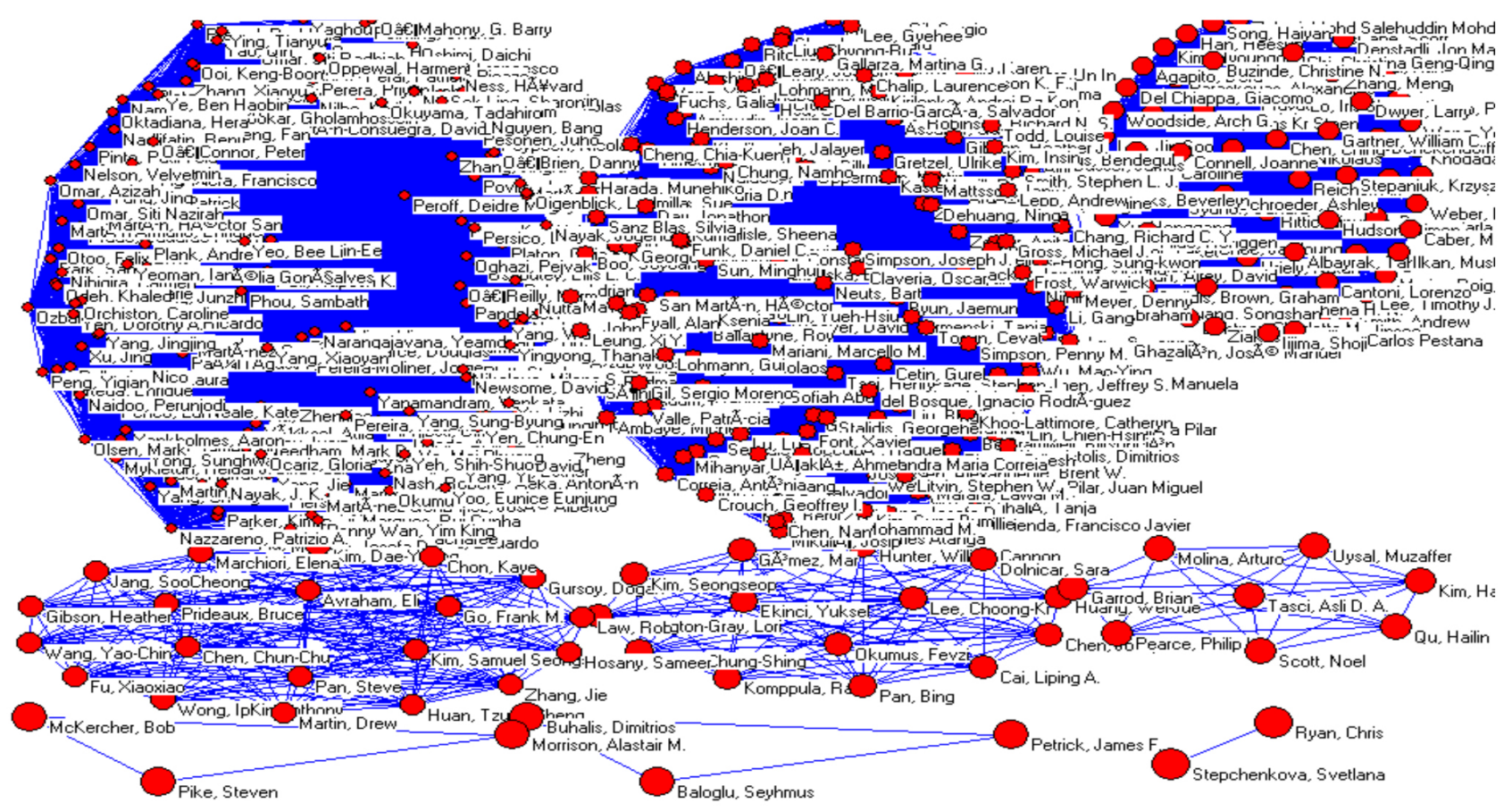

\section{CONCLUSIONS}

The importance of the image as a tool to manage tourist destinations has been studied in the last forty years by several researchers (S Baloglu \& Brinberg, 1997; Seyhmus Baloglu \& McCleary, 1999; Beerli \& Martín, 2004; Chen \& Tsai, 2007; Chi \& Qu, 2008; Fakeye \& Crompton, 1991; Gallarza et al., 2002; Gartner, 1994; Hunt, 1975; D. Kim \& Perdue, 2011; Estela Marine-Roig \& Clavé, 2016; O’leary \& Deegan, 2005; Pike, 2002; Stepchenkova, Kirilenko, \& Shichkova, 2019). Early studies where motivated by the importance growing of the tourism sector and the need to identify the role of images in the motivations of potential customers (Hunt, 1975).

The results from this research evidence the significant increase in the scientific production about destination image since the development of web 2.0 and its importance for tourism destination organizations. Some researchers agree to conclude in their papers the evolution of image during the travel stages: pre-visit, in situ and post visiting (Martín-Santana, Beerli-Palacio, \& Nazzareno, 2017). Some other approaches developed are linked to the process of image formation (Garay \& Morales Pérez, 2017; H. Kim \& Richardson, 2003; Richards, 2002); the impact of destination image in revisiting intention in the short and long term (Bigné, Sánchez, \& Andreu, 2009) and how major sport events influence the image of a particular destination (Donaldson \& Ferreira, 2009; Green, Lim, Seo, \& Sung, 2010; Nadeau, Norm, Cakmak, Heslop, \& Verwey, 2016).

Due to the nature of the construct, research topics from different disciplines have been linked to it. From this perspective, some scholars have analysed the affective component of TDI using tools and scales from psychology (S Baloglu \& Brinberg, 1997; Nassar, Mostafa, \& Reisinger, 2015; Russell \& Pratt, 1980); others have developed their research to measure the impact of marketing (Abuhjeeleh, Shamout, Sleimi, \& Harazneh, 2019); satisfaction (Hernández-Lobato, Solis-Radilla, Moliner-Tena, \& Sánchez-García, 2006); loyalty (Bhat \& Darzi, 2018; Sannassee \& Seetanah, 2015); experiential management (Cervera-Taulet, Pérez-Cabañero, \& Schlesinger, 2019); among others. In addition, the development of new technologies has created a new framework for the studies of the destination image. Social media effect on the motivations of tourist and its impact in destination image (Huertas, 2018; Lai, 2010); the role of online content through websites and blogs (Mwaura, Acquaye, \& Jargal, 2013; Sun, Ryan, \& Pan, 2015) and the employment of big data (E Marine-Roig, 2019; Qi 
\& Chen, 2019) are some of the new research lines that have aroused in the last decade.

The journals with a great extent of published articles in this field are Tourism Management (350 articles) and Annals of Tourism Research (134) articles, presenting a Pearce index of 0.47 and 0.29 respectively; while Journal of Destination Marketing \& Management is in the third place of productivity (125 articles), $90 \%$ of them being published in the last 5 years. Articles were signed by 501 authors, being Xian Li the most productive with 11 articles in the most productive journals, as evidence of the existent relationship between the most productive authors and journals. In fact, 92 articles published by 12 authors were in these journals. The maximum number of authors per article was seven, with a predominance of two and three authors per article, while the collaboration index obtained was 1.06. The main thematic descriptors are destination image, tourism, social media and tourism marketing.

The main limitations of this paper are related to the absence of analysis related to descriptive data such as Institutions, Language and Origin Country of the research, due to limitations on the access to that data.

\section{REFERENCES}

Abuhjeeleh, M., Shamout, M. D., Sleimi, M. T., \& Harazneh, I. (2019). Destination marketing for expatriates: A case study in Northern Cyprus. African Journal of Hospitality, Tourism and Leisure, 8(3), 1-19. https://doi.org/10.1016/j.dss.2007.10.001

Baloglu, S, \& Brinberg, D. (1997). Affective images of tourism destinations. Journal of Travel Research, 35(4), 11-15. https://doi. org/10.1177/004728759703500402

Baloglu, Seyhmus, \& McCleary, K. W. (1999). A model of destination image formation. Annals of Tourism Research, 26(4), 868-897. https://doi.org/10.1016/ S0160-7383(99)00030-4

Beerli, A., \& Martín, J. D. (2004). Factors influencing destination image. Annals of Tourism Research, 31(3), 657-681. https://doi.org/10.1016/j.annals.2004.01.010

Bhat, S. A., \& Darzi, M. A. (2018). Antecedents of tourist loyalty to tourist destinations: a mediated-moderation study. International Journal of Tourism Cities,
4(2), 261-278. https://doi.org/10.1108/IJTC-122017-0079

Bigné, J. E., Sánchez, I., \& Andreu, L. (2009). The role of variety seeking in short and long run revisit intentions in holiday destinations. International Journal of Culture, Tourism and Hospitality Research, 3(2), 103-115. https://doi. org/10.1108/17506180910962113

Boulding, K. E. (1956). The Image: Knowledge and Life in Society. University of Michigan Press.

Cervera-Taulet, A., Pérez-Cabañero, C., \& Schlesinger, W. (2019). Experience management as an innovative approach in emerging Mediterranean destinations. Journal of Business Research, 101, 536-547. https://doi.org/10.1016/j.jbusres.2018.11.037

Chen, C.-F., \& Tsai, D. (2007). How destination image and evaluative factors affect behavioral intentions? Tourism Management, 28(4), 1115-1122. https:// doi.org/10.1016/j.tourman.2006.07.007

Chi, C. G. Q., \& Qu, H. (2008). Examining the structural relationships of destination image, tourist satisfaction and destination loyalty: An integrated approach. Tourism Management, 29(4), 624-636. https://doi.org/10.1016/j.tourman.2007.06.007

Dávila, M., Guzmán, R., Macareno, H., Piñeres, D., De la Rosa, D., \& Caballero, C. (2009). Bibliometría: conceptos y utilidades para el estudio médico y la formación profesional. Salud Uninorte, 25, 319-330.

Donaldson, R., \& Ferreira, S. (2009). (Re-)creating urban destination image: Opinions of foreign visitors to South Africa on safety and security? Urban Forum, 20(1), 1-18. https://doi.org/10.1007/s12132-009-9053-1

Doolin, B., Burgess, L., \& Cooper, J. (2002). Evaluating the Use of the Web for Tourism Marketing: A Case Study from New Zealand. Tourism Management, 23, 557-561.

Echtner, C. M., \& Ritchie, J. R. B. (1993). The Measurement of Destination Image: An Empirical Assessment. Journal of Travel Research, 31(4), 3-13. https://doi.org/10.1177/004728759303100402 
Fakeye, P. C., \& Crompton, J. L. (1991). Image Differences between Prospective, First-Time, and Repeat Visitors to the Lower Rio Grande Valley. Journal of Travel Research, 30(2), 10-16. https://doi. org/10.1177/004728759103000202

Gallarza, M. G., Saura, I. G., \& García, H. C. (2002). Destination image: Towards a conceptual framework. Annals of Tourism Research, 29(1), 56-78. https:// doi.org/10.1016/S0160-7383(01)00031-7

Garay, L., \& Morales Pérez, S. (2017). Understanding the creation of destination images through a festival's Twitter conversation. International Journal of Event and Festival Management, 8(1), 39-54. https://doi. org/10.1108/IJEFM-04-2016-0030

Gartner, W. C. (1994). Image formation process. Journal of Travel and Tourism Marketing, 2(2-3), 191-216. https://doi.org/10.1300/J073v02n02_12

Green, B. C., Lim, S. Y., Seo, W. J., \& Sung, Y. (2010). Effects of cultural exposure through pre-event media. Journal of Sport and Tourism, 15(1), 89-102. https://doi.org/10.1080/14775081003771015

Hernández-Lobato, L., Solis-Radilla, M. M., Moliner-Tena, M. A., \& Sánchez-García, J. (2006). Tourism destination image, satisfaction and loyalty: A study in Ixtapa-Zihuatanejo, Mexico. Tourism Geographies, 8(4), 343-358. https://doi. org/10.1080/14616680600922039

Huertas, A. (2018). How live videos and stories in social media influence tourist opinions and behaviour. Information Technology and Tourism, 19(1-4). https://doi.org/10.1007/s40558-018-0112-0

Hunt, J. D. (1975). Image as a Factor in Tourism Development. Journal of Travel Research, 13(3), 1-7. https://doi.org/10.1177/004728757501300301
Kim, D., \& Perdue, R. R. (2011). The influence of image on destination attractiveness. Journal of Travel and Tourism Marketing, 28(3), 225-239. https://doi.org/10.1080/10548408.2011.562 850

Kim, H., \& Richardson, S. L. (2003). Motion picture impacts on destination images. Annals of Tourism Research, 30(1), 216-237. https://doi.org/10.1016/ S0160-7383(02)00062-2

Lai, L. S. L. (2010). The role of web-based social media in the formation of a tourism destination image. 3-12. Retrieved from https://www.scopus.com/inward/ record.uri?eid $=2$-s2.0-79955164506\&partnerlD $=40 \& m d 5=777929 d 5990 f 3 c 7 f 65 f$ 1baa0a998012f

Marine-Roig, E. (2019). Destination image analytics through traveller-generated content. Sustainability (Switzerland), 11(12). https://doi.org/10.3390/ su10023392

Marine-Roig, Estela, \& Clavé, S. A. (2016). Destination Image Gaps Between Official Tourism Websites and User-Generated Content. In Information and Communication Technologies in Tourism 2016 (pp. 253-265). https://doi.org/10.1007/978-3-31928231-2_19

Martín-Santana, J. D., Beerli-Palacio, A., \& Nazzareno, P. A. (2017). Antecedents and consequences of destination image gap. Annals of Tourism Research, 62, 13-25. https://doi.org/10.1016/j.annals.2016.11.001

Mwaura, D., Acquaye, D., \& Jargal, S. (2013). Marketing implications of the destination image of Mongolia. Worldwide Hospitality and Tourism Themes, 5(1), 80-91. https://doi. org/10.1108/17554211311292466 
Nadeau, J., Norm, O. R., Cakmak, E., Heslop, L., \& Verwey, S. (2016). The cameo effect of host country and the transitory mega-event: Patterns of effect on sponsorship evaluation for sport tourists and residents. Journal of Sport Management, 30(6), 656-671. https://doi.org/10.1123/ jsm.2016-0048

Nassar, M. A., Mostafa, M. M., \& Reisinger, Y. (2015). Factors influencing travel to Islamic destinations: An empirical analysis of Kuwaiti nationals. International Journal of Culture, Tourism, and Hospitality Research, 9(1), 36-53. https://doi.org/10.1108/ IJCTHR-10-2014-0088

O’leary, S., \& Deegan, J. (2005). Ireland's Image as a Tourism Destination in France: Attribute Importance and Performance. https://doi.org/10.1177/00472875042720lreland

Pike, S. (2002). Destination image analysis - A review of 142 papers from 1973 to 2000. Tourism Management, 23(5), 541-549. https://doi.org/10.1016/ S0261-5177(02)00005-5

Qi, S., \& Chen, N. (2019). Understanding Macao's Destination Image through User-generated Content . Journal of China Tourism Research, 15(4), 503-519. https://doi.org/10.1080/19388160.2019.1577199

Ramseook-Munhurrun, P., Seebaluck, V., \& Naidoo, P. (2015). Examining the structural relationships of destination image, perceived value, tourist satisfaction and loyalty: case of Mauritius. Procedia - Social and Behavioral, 175, 252 - 259.

Richards, G. (2002). Marketing China overseas: The role of theme parks and tourist attractions. Journal of Vacation Marketing, 8(1), 28-38. https://doi. org/10.1177/135676670200800104
Russell, J. A., \& Pratt, G. (1980). A description of the affective quality attributed to environments. Journal of Personality and Social Psychology, 38(2), 311-322. https://doi.org/10.1037/00223514.38.2.311

Sannassee, R. V, \& Seetanah, B. (2015). The Influence of Trust on Repeat Tourism: The Mauritian Case Study. Journal of Hospitality Marketing and Management, 24(7), 770-789. https://doi.org/10.1080/193686 23.2014 .934983

Sanz, S. (2008). Imagen global e intenciones futuras de comportamiento del turista de segunda residencia. Revista Europea de Dirección y Economía de La Empresa, 17, 95-114.

Stepchenkova, S., Kirilenko, A. P., \& Shichkova, E. (2019). Influential factors for intention to visit an adversarial nation: increasing robustness and validity of findings. International Journal of Tourism Cities, 5(3), 491-510. https://doi.org/10.1108/ IJTC-11-2018-0085

Stylidis, D., Shani, A., \& Belhassen, Y. (2017). Testing an integrated destination image model across residents and tourists. Tourism Management, 58, 184-195. https://doi.org/10.1016/j.tourman.2016.10.014

Sun, M., Ryan, C., \& Pan, S. (2015). Using Chinese Travel Blogs to Examine Perceived Destination Image: The Case of New Zealand. Journal of Travel Research, 54(4), 543-555. https://doi. org/10.1177/0047287514522882

Tasci, A. D. A., Gartner, W. C., \& Cavusgil, S. T. (2007). Measurement of destination brand bias using a quasi-experimental design. Tourism Management, 28(6), 1529-1540. https://doi.org/10.1016/j. tourman.2007.02.009 